\title{
Reversing the Gaze? Or Decolonizing the Study of the Qur'an
}

\author{
Sajjad Rizvi \\ Associate Professor, Institute of Arab and Islamic Studies, \\ University of Exeter, Exeter, UK \\ s.h.rizvi@exeter.ac.uk
}

\begin{abstract}
Taking as the starting point, Majid Daneshgar's Studying the Qur'an in the Muslim Academy, I argue that the political and intellectual contexts for the study of Islam and indeed the Qur'an cannot be ignored whether the study is conducted in the "Western" or the "Muslim" academy. The construction of the categories of religion and scripture arise out of practices of colonialist knowledge; positionality of the author cannot be eliminated from the interrogative gaze. Beginning with that critique, I suggest some possible ways in which we can decolonize the study of the Muslim scripture and its experience for Muslims.
\end{abstract}

\section{Keywords}

Orientalism - Qur’anic Studies - decolonization - Muslim Academy - postcolonialism

Man is not merely a possibility of recapture or of negation. If it is true that consciousness is a process of transcendence, we have to see too that this transcendence is haunted by the problems of love and understanding. Man is a yes that vibrates to cosmic harmonies. Uprooted, pursued, baffled, doomed to watch the dissolution of the truths that he has worked out for himself one after another, he has to give up projecting onto the world an antinomy that coexists with him. 
The black is a black man; that is, as the result of a series of aberrations of affect, he is rooted at the core of a universe from which he must be extricated. The problem is important. I propose nothing short of the liberation of the man of color from himself. We shall go very slowly, for there are two camps: the white and the black.

Stubbornly we shall investigate both metaphysics and we shall find that they are often quite fluid.

We shall have no mercy for the former governors, the former missionaries. To us, the man who adores the Negro is as "sick" as the man who abominates him.

Conversely, the black man who wants to turn his race white is as miserable as he who preaches hatred for the whites.

FANON 2008: 2

First published almost three decades before Edward Said's Orientalism, Black Skin, White Masks articulated the psychology of the colonial gaze in its epistemic mastery of the non-West and the construction of the "black" including his culture and his very being. What was needed was not merely to reverse the gaze and the process, for the non-West to make, subjugate, and enforce the inferiority of the West, but rather to affect a process of realizing the humanity of the colonized self in harmony with her world. Fanon's metaphysical concern was in the direction not just of a postcolonial critique but a desire for decolonization - not a negation of self and other but a desire to rethink authentically one's self and one's metaphysics. That rethinking would take place within the ultimate recognition that it is not merely the human subject as object of the gaze that is hostage to historical contingency but rather the gaze itself; what is, therefore, positionality but an explicit placing of one's historical contingency at the heart of one's experiential inquiry? (Bhabha 1994: 340-41). Said merely took the epistemic critique further in the direction of reversing the colonial gaze and pointing out the processes by which the Orient was essentialized, dominated, restructured and controlled (Said 1978: 3). This is not the place to discuss the critiques of Said-Majid Daneshgar comes to that so we will consider it — but suffice it to say, concurrent with Wael Hallaq's recent restatement, that Orientalism as a polemic went too far in allegedly dismissing the entire corpus of Western knowledge about the Orient as complicit in a relationship of power, coercion and control (applying the same monolithic 
essentialization of the West as had been practiced for the Orient), but at the same time did not go far enough since it failed to critique its own secular liberal assumptions (Hallaq 2018: 17-21). The Qur'an as an integral part of that Orient was thus not a bearer of meaning for Muslims, nor was what Muslims thought about the Qur'an of any relevance, nor was it a multi-faceted reality that informed and punctuated the lives of Muslims; it was merely a site of domination to be redefined and controlled in order to effect a control of Muslims (Said 1978: 6o-63).

A constructive project needs to go beyond the temptation to reverse the gaze to 'shame' the occident (see Dabashi 2020). The postcolonial struggle-or even the actual and imagined spaces of the postcolony-should afford us the possibility of thinking beyond earlier binaries, not least because it is defined less by a historical epoch and geographical location and more but a state of mind or attitude. Yet the postcolony as the contemporary location writ large squeezes the possibility of (seemingly) rational discourse about subjects and objects; in a culture of assumed constructivisms of self and other, of tradition, text, and inquiry, we have to be seen to be rational in order to appear human (Mbembe 2001: 1-3). ${ }^{1}$ The question is whose rationality is taken as axiomatic and whether that mode of reasoning, of critique, of 'history' are universally binding categories that define us, in Aristotelian terms, as human. Historical-critical ("Western," "rational," "academic") studies on the text of the Qur'an-its redaction and canonization - tended to dismiss what was deemed the traditional 'fix' of the emergence of the text and its "consistency" in internalist Muslim accounts of their religion and the canonization of the text; to put it rather starkly, the naïve native could not be trusted when it came to accounting for the historical formation of the tradition, or the linguistic frameworks needed to decipher it, or even the hermeneutical skill required to make sense of scripture. Thomas Macaulay's famous dismissal of oriental learning is rather indicative of that colonial practice. Correct philology-indeed etymology of the Arabic language - is far too important to be left to the Arabs (Saleh 2005). On the other hand, some Muslim traditionalists ("believers," "holders of truth") would have held that, at least post-Orientalism, or one might even say after the fact of the checkered history of the demonization and caricaturization of the Islamic tradition from the medieval period onwards, 'Western' nonMuslims cannot be trusted with the study of the Qur'an, in which their claim

1 The postcolony is thus the default state of humans and not the exception, just as Giorgio Agamben has reminded us that the state of exception in which the sovereign defines the exception and implements a sets of policies determining the ethical and political import of persons as bare life and not citizens with rights and checks upon the sovereign, and that the concentration camp as the space for biopolitics is not the exception but the norm-see Agamben 1999 and 2005. 
to 'critical method' masks their hostile intent to deny and undermine 'truth'. The locus classicus of that Muslim rejection of Orientalist Qur'anic studies is Parveez Manzoor's famous and oft-quoted passage:

The Orientalist enterprise of Qur'anic studies, whatever its other merits and services, was a project born of spite, bred in frustration and nourished by vengeance: the spite of the powerful for the powerless, the frustration of the "rational" towards the "superstitious" and the vengeance of the "orthodox" against the "non-conformist."

MANZOOR 1987: 39, cited in RIPPIN 2012: 3

Joseph Lumbard's unpublished paper on the decolonization of Qur'anic studies extends the critique to undermine Andrew Rippin's suggestion that the divide between the critical and the gullible needs to be bridged through engagement with modern Muslim Quranic studies; it is the oblivion of centuries of Arabic philologies, 'ulüm al-Qur'an, and especially Qur'anic exegesis, that seems rather stark. ${ }^{2}$ Orientalist objectification and dominance of the non-West extends to the consideration of the intellectual heritage of the other as inferior. The choice between "researchers" (bāhithün) and orientalists (mustashriqūn) is not productive.

Daneshgar's new study of the 'Muslim academy' seeks to go beyond that binary and consider how we turn the gaze away from the study by the Western (non-Muslim) academy to a self-critical intra-Muslim study of the academy with the base assumption, that he draws from the Indian-American philosopher Akeel Bilgrami, that seems to valorize the academy (the Western metropolitan one no less) as a neutral site for intellectual inquiry and research and the pursuit of truth and pedagogy in search of further research (Bilgrami 2014: 76, cited in Daneshgar 2020: xxii). This is somewhat startling because the view from nowhere is a hollow-and unrealizable — claim no least because it evinces a denial of the ethical and the political, the affective as well as the embodied (Gandhi 2006: 178-79). Concepts like religion are not free-standing mind-independent essences but rather elements of the cognitive states of persons bearing intentionality. Despite framing his inquiry within his own positionality coming from an Iranian Shi'i background and having studied partly in the seminary and asking the methodological question of one's belonging and stake in inquiry, Daneshgar does not have much sympathy for post-Orientalist and postcolonial critiques of Qur'anic Studies. After a critical appraisal of elements of his arguments, I will contend that what the academic study of the

2 See https://www.academia.edu/29844072/Decolonializing_Quranic_Studies accessed 19 April 2020. 
Qur'an needs is a double movement of decolonization; a postcolonial critique of the epistemology of academic Quranic studies (which follows from critiquing the category of religion as universalized from the European case) does not go far enough. In what follows I will begin with the postcolonial critique of the study of religion and especially Islam and the Quran-since the precise merit of Daneshgar's work is to force us to think about position and methodfollowed by a critique of his argument, and conclude with some suggestions for what a decolonized study of the Qur'an and its ontological and social statuses may allow.

Daneshgar acknowledges but does not engage with the postcolonial critique of religion and of Orientalist Islamic studies. The methodological study of religion is somewhat caught in a bind. The possibility of the meaningful use of the category of religion, of scripture, or ritual requires us to find elastic but precise definitions of these terms that apply across cases. But it is still the case that the practice involves the universalization of a notion of religion that is determined and constructed in a particular European historical genealogy since the Reformation and especially since the Enlightenment: religion is a private set of beliefs and cognitive states to which one assents, and scripture is to considered an expression of a private conversation with the beyond-but in both cases elements of tradition and the past which we have foregone in our quest for modernity and the assumption of progress (Asad 1993, Allen 2017). The Enlightenment project of religion suggests the triad of notions: subjectivity of the religious person and his individuality over the communal (and the transcendent), moral agency that is negotiated and immediate and no longer absolute, and religion purely within the bounds of "reason" begging the question of whose rationality. Both religion and its opposite-secularity-are mutually constructed features of the modern world (Asad 2003, Taylor 2007). ${ }^{3}$ This modern concept of religion - and indeed world religion - is thus an outcome of European historical contingency and yet is considered a timeless, and universal social fact (Nongbri 2013:154). Its particularity is universalized in the guise of an embrace for tolerance and pluralism (Masuzawa 2005). And further one wonders what is meant by religion: a metaphysics or ontology of thing or things? A faith or set of beliefs? An identity and affirmation of selfhood? A set

3 There are far more radical critiques of the categories of religion, belief, 'God', sanctity and so forth in continental philosophy of religion that takes its cue not just from the poststructuralist distrust of stable categories and neat definitions but also from the medieval Christian mystical traditions' modes of apophasis. Thus theism, in theological mode, gives way to anatheism, God to the 'god who may be', and belief to some authentic feeling of attachment and not the analytic assent to truth claims, and in which the sacred and the religious need to be rethought and reconceptualized—see Kearney and Zimmermann 2016. 
of political practices? An ethics without an ontology? Or even as the exotic other of modernity?

One of the modern ways in which religion is controlled, especially in colonialist epistemology and then in the postcolony, is through the "reign of quantity," according to which the notion of number identifies, indexes, restructures and controls (Appadurai 1993). The traditionalist thinker quite opposed to modernity and modern religion René Guénon (1886-1951) famously wrote about the obsession with quantity and the eschewal of quality in modernity. Quantity - that is conflated with the "scientific" — concerns the descent away from the metaphysics of quality and of a principle that is unquantifiable (Guénon 2004, cited in Hallaq 2018: 143-64). The dominance of quantity over quality is then reflected in the obsession of much Quranic studies in the mechanics of the text and its philology, deliberating bracketing not just the ontology of the text but also its meaning and forms of its textuality to which I will return at the end. ${ }^{4}$

The recognition of how decolonization of the study of religion begins with the category of religion and the secular has then been extended to a number of cases. Religions in the non-West were exoticized and orientalized both in the German and in the British imagination (King 1999, Park 2014, Gandhi 2006). Further, Peter van der Veer has shown how in the colonial period Islam and Hinduism were remade in the image of the successful and muscular imperial Protestantism of the colonial overlord with the assumption about one God, one scripture, and one source of authority—but also that the colonial experience had a blowback on conceptualization in imperial Britain van der Veer 2001, Gottschalk 2012, Cohn 1997, Mehta 1999). This is of course not to argue that Islam and Hinduism were invented in the colonial epistemology but rather that the categories were made and refashioned in that context (Nicholson 2013). It is the porous nature of the imperial boundaries and the failure of the colonial project to separate and partition in order to avoid the contagion of the non-Western other (as well as the genealogical inquiry into it) that opens the space for a move towards a decolonial space, the place for a fulfilled ethics of friendship and cooperation (Gandhi 2006: 2-3, Bhabha 1994: 91-95, 175). Nevertheless, the promise of a secular, indeed post-secular, religion and its rationality, the manner in which the terms are defined and controlled is a political act, not of democratization and opening up possibilities but of shutting down tradition, neglecting history (Abeysekara 2008). While postcoloniality is either a persistence of a colonial past or a promise of freedom yet

4 It is also worth mentioning the genetic fallacy of origins - as if we shall find the Ur-text whence the Qur'an that will finally explain why Muslims have been so very mistaken. 
to come, decoloniality requires a careful genealogy of how we got here, a critical account that is not only diagnostic but can also enable us to transcend the colonial imprint on subjectivity and social life. There is thus an inbuilt cultural bias in much theoretical approach to the study of religion (not least because of the return of Hegel to that critical theory) - and perhaps that requires a further problematization of the category of "religio" and thinking through and with religion and not just about so that we take indigenous categories seriously (Pal-Mandair 2009). It is striking just how many specialists of the study of religion would agree with Marx that "the criticism of religion is the premise of all criticism," or rather like Bruce Lincoln that the primary function of the historian of religion is to debunk and critique religious metaphysics and imaginings of the world (but never to wonder if secularity has become the new master narrative that haunts the study of religion) (Marx cited in Pal-Mandair 2009: 384). This need not to lapse into an incommensurability in which each religio is sui generis; but is naturalism and secular humanist recourse to the authority of "history" the only alternative? (Pal-Mandair 2009: 290-92, critiquing McCutcheon 2000). There is no reason to think that the Western academy's conception of religion and history are axiomatic. It may be easy to assert the Christian roots of our notion of religion and scripture-but that acknowledgement is not sufficient for decolonization; we need a "rigorous historical investigation that does not surreptitiously yield to the comforting belief in the liberating power of 'historical consciousness"' (Masuzawa 2005: 327-28).

Where do we go with the category of religion and indeed of scripture? What sorts of concepts are these and how do they map onto ontology, and assume a particular philosophy of language? Cavell raises this critical problem of the elasticity of the concept and its communicability:

If words and phrases must recur (which means that they must be projected into new contexts, which means that the new contexts must tolerate or invite that projection); and if there are no rules or universals which insure appropriate projection, but only our confirmed capacity to speak to one another; then a new projection, though not at first obviously appropriate, may be made appropriate by giving relevant explanation of how it is to be taken, how the new context is an instance of the old concept. If we are to communicate, we mustn't leap too far; but how far is too far?

CAVELL 1979: 192; see also MOI 2009

What would a decolonial theory of Qur'anic studies look like? At one level it would need to take as given not just the older debate about 
Orientalism - morphing into Islamophobia-in which Islam is taken as a monolithic give, an essence discernable in text and exemplified in a scriptural legal tradition (Ahmed 2015). Let us turn to Daneshgar's argument and consider its methodological proposal. It is a study in the politics of the Muslim academy and its apologetics that, while accepting the politics of the Western academic method in passing, seems to advocate a joined up study of Islam and the Qur'an that brings together the 'best of the academic method' married with the 'best Eastern philology' towards a position of study that maintains a "critical but respectful approach to the Qur'an": the best way forward is a diversity of Muslim and non-Muslim approaches, and the special appeal here is to Muslims to open up. There is much to unpack just here-but it is further authenticated by an affirmation of his own positionality as an Iranian Shici brought up in the tradition and who studied in the Muslim academy, a position that threatens to slide into the sort of pleading for specialist insider ("native") information that Said's Orientalism is often accused of privileging. At one level this is a rather depressing study: the Muslim academy (by which he says he does not mean the seminaries but studies in universities and other state-funded institutions) is defined by apologetics that is designed to defend and shield believers from criticism of their faith and by a complete sectarianization and skewing of vision that denies a voice to any other perspective (whether internal to Islam or external), while the political correctness of the postmodern metropolitan academy increasingly self-censors in order to avoid critiques of orientalism and prejudice. The Muslim academy willfully censors in a paternalist desire to protect the "weak," and the Western academy does so to protect itself from the attack of the "epistemologically" weak. "The study of Islam is more political than generally represented." Nevertheless, the truth is out there - and the goal of inquiry - if only we would pursue it. Along the way he criticizes postcolonial and postmodern perspectives not least those coming from anthropology and sociology: the appeal to community experience of Muslims, for Daneshgar, cannot explain critical elements of the text and the tradition that seem to bear an independent ontological status. Two consistent examples are presented of Islamic apologetics with respect to the Quran. The first is the contrasting way in which the story of Zayd bin Hāritha is considered by Western and Muslim academics, the former try to get to the truth and ask why the story is presented in that way and how the doctrine of the "seal of prophecy" comes about (exemplified in the two works by David Powers), and the latter deny any questions to avoid any criticism of either the inerrancy of the revelation or of the Prophet. The second is the study of science of the Qur'an which is broadly ignored in the Western academy (except perhaps among those interested in modern Muslim theologies) while heavily engaged in the Muslim academy as an element of the 
exposition of the miraculous nature of the revelation. What sort of realistic dialogue is even possible in such a stark cultural dissonance? Acknowledging that Western studies are "Eurocentric," Islamic apologetics is further exemplified in the translations and use of Said to demonize the Western academy, ignoring critiques of Said. Islamic apologetics is therefore complicit in what Sadeq al-Azm famously called "orientalism in reverse" (al-Azm 1981; see also Devji and Kazmi 2017). Daneshgar then invokes Lumbard as arguing for a dismissal of Western Qur'anic studies because of its colonialist epistemologies. But that is not Lumbard's claim - and not what decolonization involves. It is too easy to conflate decolonization (and postcolonialism) as an extension of the most uncharitable reading of Orientalism, just as it would be incorrect to dismiss the entirety of academic Qur'anic studies in the West as hostile based on one's reception of Ibn Warraq, the Inara group, and others.

Ultimately one is left with either a sympathetic or unsympathetic reading of Daneshgar's diagnosis of the Muslim academy. The latter reading would entail considering the Western academy to be critical, discerning, and in pursuit of the truth because of its adherence to the value of 'history', and to dismiss the Muslim academy as overly politicized, not concerned with the truth but merely with a defense of "tradition," and uncommitted to history because the faith transcends history. Any talk of a dialogue seems therefore hollow and in effect, a call for Muslim academics to reject their traditions and adopt the "Western method." A more sympathetic reading is that since there are plenty of studies of politics, orientalism and cultural bias in the Western academy and no "taboo-breaking" studies of the politics of the Muslim academy, it is entirely reasonable for Daneshgar to focus on the Muslim context - and warn about the "universalization of Islamic apologetics" The possibility of the universalization of Western apologetics is not really countenanced.

A decolonizing practice of Qur'anic studies is needed not because Islamic apologetics need to be universalized and the West "shamed" into allowing the subaltern religious person to be human and to speak, but rather in order to save the academic enterprise from descending into a set of apologetics for colonialist epistemological projects. Decolonization is not about replacing one hegemonic discourse with another but about opening up, disrupting, dislocating the specter of the West's globalizing model, the rhetoric of modernity (and rationality), and the logic of coloniality. It needs to move us from the embrace of the universal to the pluriversal and the interversal which does not exclude the Western (Mignolo and Walsh 2018: 2-3). One might object that decolonization is not just a disruption in the academy if it fails to deal with the actual politics of alterity and subjugation through racism, sexism and the dominance of natures. So actual politics count and not merely academic politics. But 
the violence of the discourse, of structures of thought and categorization, of institutions and their habitus and rules, is precisely the objective social fact of coloniality and Western modernity. Another objection might be whether one ought to consider coloniality and the imperial project of separate to be uniquely Western: what about Islamic imperial practices of alterity and subjugation that are reflected in the disciplines of learned culture including the 'ulüm al-Qur'ān? That is exactly where decolonization needs to make a double movement against the Western academic study as well as totalizing Muslim imperial projects - that is not just a call for sectarianization (whose threat is well noted by Daneshgar) but again a move to plurality, not in the safe space of tolerating the other by practices of controlling inclusion. Islamic intellectual history cannot merely follow one hegemonic path to the exclusion of others; it needs to interrogate the triad of modernity, progress, and rationality (the latter in particular affects the study of exegesis and philosophical hermeneutics thus exoticizing and hereticating 'Sufi' commentaries and the esoteric and placing them beyond the canon in both Western and imperial Muslim accounts for the field).

So how do we move forward? The first step is to consider a critique of the habitation of modernity in which the academic study dwells and effect a provincialization of the European gaze, not just through the use of elements of European thought (one thinks of Dipesh Chakrabarty's Marxism as well as Heidegger) but also consider the possibility of forging a "theoretical framework" for the study of religion that comes from the non-West-how about a theory of studying the Qur'an that actually comes from the likes of Ibn 'Arabī and Mullā Ṣadrā, or even "non-canonical" figures such as Ashraf 'Alī Thānvī or Sayyid 'Alī Naqī Naqvī? (see Chakrabarty 2000 and 2002). But more so that that - a theory of studying the Buddhist sutras, the Dao te ching, and even the Bible based on the hermeneutics of Fakhr al-Dīn Irāqī? This is not in order to dominate and locate within an inclusivist framework of inquiry but rather to open up the possibilities of metaphysics and of human inquiry cognizant of the positionality of the agent.

Second, we might want to consider the multivalency of the Quran itself. It is not just that much of the tradition of academic Qur'anic studies rejects the utility of exegesis or rather sees it merely as an exercise in self-revelation and expression of the training of the exegete (the ultimate eisegesis). One has to consider whether the text speaking directly to the self and as a series of symbols bearing meanings that need to be deciphered in the inscribed text may betray a Protestant, colonial epistemology of scripture. Here I propose one way in which exegesis needs to be rethought in the light of the four levels through which the Qur'an may be encountered and lived-and this is about 
awareness of those levels and not the requirement for the gaze to be Muslim. The first level is through the Qur'an as a textual artefact, a book, a scripture, an object of veneration or recitation and contemplation, a collection of inscribed words that have a structure, syntactical arrangement, and strings of meanings as expressed in narrations that stress the importance of a venerable treatment of the artefact and reading the scripture in a book (mușhaf) (al-Kulaynì 1981, hadith no. 3519, k. fadl al-Qur'ān Ch. VII, no. 1, IV: 626). We normally understand exegesis at this level as a learned, scholastic discourse intended to reveal layers of meaning, from the lexical to the narratological to the experiential (Fischer and Abedi 1990: 95-102; MacAuliffe et al. 2002; Bauer 2013; Hamza and Rizvi 2008). The process of exegesis, of the dialectics of engaging with the text and the many intellectual contexts that constitute the "semiosphere" of it, a field in which sign processes operate within a context, is an expression of the art of living, the cultivation of values, the dissemination of correct comportment ( $a d a b$ ), and the civilizing mission (Lotman 1990: 123-27, cited in Ahmed 2015: 359-6o; see also Nehamas 1998, Elias 1994, and Metcalf 1984 on civilizing comportment and forms of life). But this level of encountering the Qur'an can include the role that the artefact plays as a talisman, as a purveyor of spiritual power, as a source of augury (istikhāra) and geomancy ( $\mathrm{raml}$ ), a magical book by which one protects, casts aspersions upon another, and heals (Loeffler 1988: 274-86, and works like Nāșirī 2004). The plenitude of meaning, which, as we saw above, embraces the exoteric and esoteric and much beyond, and the polyvalence of the text should not require much further argument.

The second level is through the Qur'an as a signifier within the intertextual weaving and production of cultural, intellectual and aesthetic capital that we all experience and consume. Exegesis at this level articulates and elucidates elements of the "logosphere" of the Qur'an, the field in which the scripture is articulated, uttered and expressed linguistically. In this sense, while believers often stand in awe of the text, they have already experienced the architectonics of the Qur'an in the very fabric of Muslim life. As the famous saying goes, God is beautiful and loves beauty, and the very expression of the Qur'an in its different articulations and presentations follows that maxim in which the contingencies of aesthetic harmony and form act as homologies for the Divine (Gonzalez 2001: 26-41, Elias 2012). Discerning and perceiving the beauty of the Quran is not simply an act of textual reception but of aesthetic perception of life imbued with 'Qur'anicity'; appreciation of that art does require cultural literacy such that someone who is functionally illiterate recognizes the calligraphic tokens, the melodies and intonation of recitation, the motifs in the plastic arts, and the signatures and citations in music (Metcalf 2009: 93-119). The beauty of the Divine, manifest in the cosmos, is 
remade and reshaped in the aesthetics of human craft-that mimesis of the Divine must contain elements of imperfection and human error in order not to fall into idolatry by considering the Qur'an as either shibboleth or an idol Elias 2012: 147). It is here that Henry Corbin's famous admonition about the distinction between an idol and icon is salutary (Corbin 1981: 358-64). The former entails a contraction of the Divine, a location of theophany and power within an object that in itself becomes the focus of veneration and does not allow one to see beyond, while the latter retains its role as a symbolon that propels the perceiver to use their imagination to go beyond the physical artefact and contemplate the "theophanic form. ${ }^{5}$ Or to use another analogy that Corbin draws, it is like the distinction between 'existents' which can act as a veil that ushers in phenomenal multiplicity and "being" that is the True One that underlines all that exists - one can marvel at the multiplicity and stop there, indulging in idolatry, or one can look at the underlying reality and recognize that each "existent" is an icon that reveals Being. It is also encountering the Qur'an in an indexical manner in the way in which much Islamic literature bears the hallmarks of Qur'anicity, by merely citing, acknowledging or referencing the scripture without deriving or marking out its meaning in the production of a new text. This attraction to what is familiar is that same inclination that inspires love for the original signifier, both the Qur'an and its revelator, by evoking the human faculties of the external senses as well as the internal senses of the intellect, insight and intuition, and divine inspiration and illumination in the heart (al-Ghazālī 1975, II: 572-73, cited in Elias 2012, 164-65).

The third level is through the Qur'an as a primordial, timeless reality revealing the nature of the cosmos, the light and the guide that requires rehearsal and teaching among people, and as a mediating reality (al-Kulaynī 1981, hadith no. 3519, k. fadl al-Qur'àn, IV: 596-606). Exegesis of this kind is the "archosphere" of the Qur'an, the field that pursues the origins and the principle whence the scripture came. This is partly what the tradition understands by the teaching or revelation in its first instance, in which it exists on the heavenly, pre-eternal "Preserved tablet" (al-lawh al-mahfüz), as well as by the pre-eternal "Muhammadan light" (al-nūr al-muhammadī) in the form of the person of the Prophet (and the imams, according to Shici traditions) who was the first beloved made to stand apart from the first Lover (Heiler

5 It is, perhaps, the Qur'an as idol, as authority in itself to which one unreflectively genuflects that was best exemplified in the topos of 'raising the text on lances' at the Battle of Șiffin in 37/657. In this role as idol, the Qur'an challenged the authority and person of the imam, the living Qur’an; see Fischer and Abedi 199o: 106, and Amir-Moezzi 2011. 
1961: $35^{1-52}$, Rubin 1975, Schimmel 1985). Allied to this notion, albeit in a more historically contingent sense, is Shahab Ahmed's notion of the 'pre-text' (Ahmed 2015: 346ff).

The fourth level is through the Qur'an as a recitation ( $q$ ira $\bar{a}^{3}$, $\left.\operatorname{tarti} l\right)$ and cantillation (tajwid), the power of the uttered word of God, doubled in its potency when articulated on the tongue of the imam (al-Kulayni 1981, hadith no. 3524, k. fadll al-Qur'ān, IV: 614-19). Exegesis of this kind concerns the "phonosphere" of the Qur'an, the aural field in which the scripture is encountered. Recitation becomes a means not only of internalizing the text and the Divine, of meeting the imam, but also of aesthetic embellishment and achieving healing and therapy of the self and one's immediate context within conventional modes and registers (Nelson 2001, Ware 2014, esp. 62-67). Alongside the rational exhortation to those listening, the poetic register evinces similar stylistic responses in the reciter and in the listener (Kresse 2007: 107-8, Fischer and Abedi 1990: 107-11). Evoking imagery (takhyill) and provoking poetical argumentation and rhetoric is central to the notion of what is beautiful in the language of revelation (Kermani 2015: 133-84, van Gelder and Hammond 2009). These processes of cultural production from the phonosphere remained efficaciously imaginary whether the articulation was in the Arabic or in some vernacular (see Zadeh 2012).

Finally, decolonization does not mean a theologization of the problem of the study of the Quran but still a recognition that theology does matter. It attempts to strike a path at an integrated and reparative study that acknowledges and tries to overcome the restriction of politics, asking the critical question of authenticity and whose authority underlies the perspective, without reverting to a thorough relativism in which each perspective is valid. It needs to effect a productive and constructive program of understanding that forgoes the fiction of the "academic view from nowhere." No one will deny that this is difficult not least because we may not have the right language for a properly reparative, decolonial curriculum and method for the study of Islam and the Qur'an; the hope and expectation of that linguistic turn is an element of the soteriology of decoloniality.

\section{Acknowledgements}

I am grateful to Professor Ali Altaf Mian for some references and suggestions on the decolonisation of the study of religion as well as his judicious reading of the paper. Any mistaken digressions and undigested ruminations remain stubbornly mine. 


\section{References}

Abeysekara, Ananda (2008). The Politics of Postsecular Religion: Mourning Secular Futures. New York: Columbia University Press.

Agamben, Giorgio (1999). Remnants of Auschwitz: The Witness and the Archive. Tr. Daniel Heller-Roazen. Cambridge, Mass.: MIT Press.

Agamben, Giorgio (2005). The State of Exception. Tr. Kevin Atell. Chicago: University of Chicago Press.

Ahmed, Shahab (2015). What is Islam? The Importance of being Islamic. Princeton: Princeton University Press.

Allen, Amy (2017). The End of Progress: Decolonizing the Normative Foundations of Critical Theory. New York: Columbia University Press.

Amir-Moezzi, Mohammad Ali (2011). Le Coran silencieux et le Coran parlant: Sources scripturaires de l'islam entre histoire et ferveur. Paris: CNRS.

Appadurai, Arjun (1993). Number in the colonial imagination. In Carol A. Breckenridge and Peter van der Veer, eds. Orientalism and the Postcolonial Predicament. Philadelphia, Penn.: University of Pennsylvania Press, pp. 314-39.

Asad, Talal (1993). Genealogies of Religion:Discipline and Reasons of Power in Christianity and Islam, Baltimore: The Johns Hopkins University Press.

Asad, Talal (2003). Formations of the Secular: Christianity, Islam, Modernity. Stanford, Calif:: Stanford University Press.

al-Azm, Sadiq Jalal (1981). Orientalism and orientalism in reverse. Khamsin 5: 5-26.

Bauer, Karen (2013). Aims, Methods, and Contexts of Qur'anic Exegesis (2nd/8thgth/15th C.). Oxford: Oxford University Press.

Bhabha, Homi (1994). The Location of Culture. London: Routledge.

Bilgrami, Akeel (2014). Secularism, Identity, and Enchantment. Cambridge, Mass.: Harvard University Press.

Cavell, Stanley (1979). The Claim of Reason: Wittgenstein, Skepticism, Morality, and Tragedy. New York: Oxford University Press.

Chakrabarty, Dipesh (200o). Provincializing Europe: Postcolonial Thought and Historical Difference. Princeton: Princeton University Press.

Chakrabarty, Dipesh (2002). Habitations of Modernity: Essays in the Wake of Subaltern Studies. Chicago: University of Chicago Press.

Cohn, Bernard (1997). Colonialism and its Forms of Knowledge: The British in India. Princeton: Princeton University Press.

Corbin, Henry (1981). La philosophie iranienne islamique aux XVII et XVIII e siècles. Paris: Buchet Chastel.

Dabashi, Hamid (2020). Reversing the Colonial Gaze: Persian Travellers Abroad. Cambridge: Cambridge University Press. 
Daneshgar, Majid (2020). Studying the Qur'ān in the Muslim Academy. New York: Oxford University Press.

Devji, Faisal and Zaheer Kazmi (2017). Islam after Liberalism. London: Hurst \& Co.

Elias, Jamal J. (2012). Aisha's Cushion: Religious Art, Perception, and Practice in Islam. Cambridge, Mass.: Harvard University Press.

Elias, Norbert (1994). The Civilizing Process. Tr. Benjamin Jephcott. Oxford: Blackwells. Fanon, Frantz (2008). Black Skin, White Masks. Tr. Charles Lam Markmann. London: Pluto Press.

Fischer, Michael M.J. and Mehdi Abedi (1990). Debating Muslims: Cultural Dialogues in Postmodernity and Tradition. Madison, Wisc.: University of Wisconsin Press.

Gandhi, Leela (2006). Affective Communities: Anticolonial Thought, Fin-de-siècle Radicalism, and the Politics of Friendship. Raleigh, NC: Duke University Press.

van Gelder, Geert Jan and Marlé Hammond (2009). Takhyül: The Imaginary in Classical Arabic Poetics. Exeter: The Gibb Memorial Trust.

al-Ghazālī, Abū Ḥāmid (1975). Kìmìya-yi sacãdat. Ed. Ḥusayn Khadīw-jām. Tehran: Intishārāt-i īlmī u farhangī.

Gonzalez, Valerie (2001). Beauty and Islam: Aesthetics in Islamic Art and Architecture. London: I.B. Tauris in association with the Institute of Ismaili Studies.

Gottschalk, Peter (2012). Religion, Science and Empire: Classifying Hinduism and Islam in Colonial India. New York: Oxford University Press.

Guénon, René (2004). The Reign of Quantity and the Sign of the Times. Tr. Lord Northbourne. rpt. Cambridge: Philosophia Perennis.

Hallaq, Wael (2018). Restating Orientalism: A Critique of Modern Knowledge. New York: Columbia University Press.

Hamza, Feras and Sajjad Rizvi (2008). An Anthology of Qur'anic Commentaries, Volume I: On the Nature of the Divine. Oxford: Oxford University Press.

Heiler, Friedrich (1961). Erscheinungsformen und Wesen der Religion. Stuttgart: Kohlhammer.

Kearney, Richard and Jens Zimmermann (2016). Reimagining the Sacred: Richard Kearney Debates God. New York: Columbia University Press.

Kermani, Navid (2015). God is Beautiful: The Aesthetic Experience of the Quran. Tr. Tony Crawford. Cambridge: Polity Press.

King, Richard (1999). Orientalism and Religion: Postcolonial Theory, India, and the Mystic East. London: Routledge.

Kresse, Kai (2007). Philosophising in Mombasa: Knowledge, Islam and Intellectual Practice on the Swahili Coast. Edinburgh: Edinburgh University Press.

al-Kulaynī, Abū Ja'far (1981). al-Käfì. Ed. 'Alī Akbar Ghaffārī. 8 vols. Beirut: Dār al-ta'āruf. Loeffler, Reinhold (1988). Islam in Practice: Religious Beliefs in a Persian Village. Albany, NY: State University of New York Press. 
Lotman, Yuri (1990). Universe of the Mind: A Semiotic Theory of Culture. Bloomington, Ind.: Indiana University Press.

MacAuliffe, Jane Dammen, Barry D. Walfish and Joseph W. Goering (2002). With Reverence for the Word: Medieval Scriptural Exegesis in Judaism, Christianity, and Islam. Oxford: Oxford University Press.

Manzoor, Parvez (1987). Method Against Truth: Orientalism and Qur'anic Studies. Muslim World Book Review 7: 33-49.

Masuzawa, Tomoko (2005). The Invention of World Religions, or How European Universalism was Preserved in the Language of Pluralism. Chicago: University of Chicago Press.

Mbembe, Achille (2001). On the Postcolony. Berkeley: University of California Press, 2001.

McCutcheon, Russell T. (2000). Manufacturing Religion: Sui Generis Religion and the Politics of Nostalgia. New York: Oxford University Press.

Mehta, Uday Singh (1999). Liberalism and Empire: A Study of Nineteenth Century British Liberal Thought. Chicago: University of Chicago Press.

Metcalf, Barbara (1984). Moral Conduct and Authority: The Place of adab in South Asian Islam. Berkeley, Calif.: University of California Press.

Metcalf, Barbara (2009). Islam in South Asia in Practice. Princeton: Princeton University Press.

Mignolo, Walter D. and Catherine E. Walsh (2018). Decoloniality: Concepts, Analytics, Praxis. Durham, NC: Duke University Press.

Moi, Toril (2009). They practice their trade in different worlds: Concepts in poststructuralism and ordinary language philosophy. New Literary History 40.4: 801-24.

Nāṣirī, Muhạmmad Bāqir (2004). al-Durū' al-ḥașina wa’l-kunūz al-dafina. Beirut: al-Mahajja al-bayḍā’.

Nehamas, Alexander (1998). The Art of Living: Socratic Reflections from Plato to Foucault. Berkeley, Calif.: University of California Press, 1998.

Nelson, Kristina (2001). The Art of Reciting the Qur'an. Cairo: The American University in Cairo Press.

Nicholson, Andrew (2013). Unifying Hinduism: Philosophy and Identity in Indian Intellectual History. New York: Columbia University Press.

Nongbri, Brent (2013). Before Religion: A History of a Modern Concept. New Haven, Conn.: Yale University Press.

Pal-Mandair, Arvind (2009). Religion and the Specter of the West: Sikhism, India, Postcoloniality, and the Politics of Translation. New York: Columbia University Press.

Park, Peter K.J. (2014). Africa, Asia, and the History of Philosophy: Racism and the Formation of the Philosophical Canon, 1780-1830. Albany, NY: State University of New York Press. 
Rippin, Andrew (2012). The reception of Euro-American scholarship of the Qur'an and tafsir: An overview. Journal of Qur'anic Studies 14.1: 1-8.

Rubin, Uri (1975). Pre-existence and lights_-aspects of Nūr Muhammad. Israel Oriental Studies 5, pp. 52-119.

Said, Edward W. (1978). Orientalism: Western Conceptions of the Orient. London: Penguin.

Saleh, Walid (2005). The etymological fallacy and Qur'anic studies: Muhammad, Paradise, and Late Antiquity. In Angelika Neuwirth, ed. The Qur'ān in Context: Historical and Literary Investigations into the Qur'ānic Milieu, 649-698. Leiden: Brill. Schimmel, Annemarie (1985). And Muhammad is His Messenger: The Veneration of the Prophet in Islamic Piety. Chapel Hill, NC.: University of North Carolina Press.

Taylor, Charles (2007). A Secular Age. Cambridge, Mass.: Belknap Press.

van der Veer, Peter (2001). Imperial Encounters: Religion and Modernity in India and Britain. Princeton: Princeton University Press.

Ware, Rudolph T. (2014). The Walking Qur'an: Islamic Education, Embodied Knowledge, and History in West Africa. Chapel Hill: University of North Carolina Press.

Zadeh, Travis (2012). The Vernacular Qur'an:Translation and the Rise of Persian Exegesis. Oxford: Oxford University Press in association with the Institute of Ismaili Studies. 